\title{
10 \\ Post-hybridity Bargaining and Embodied Accountability in Communities in Conflict, Mozambique
}

\author{
Victor Igreja
}

\section{Introduction}

Students of anthropologies of Africa would have frequently heard the everyday expression, 'one leg does not dance alone'. Many Africans often like to reiterate the collective nature of their endeavours, even if this is not always the case, so that, to return to the proverb, the origin and durability, type and size, and gender and colour of the second leg does not matter, so long as the dance can be performed. The late Terence Ranger designated this sense of practical reasoning to face diverse life events as 'creative and resilient pluralism', which is embedded in histories of contradiction and contestation through appropriation and innovation. He suggested that such practical sense 'helps to explain the remarkable adaptability of African societies and individuals during changes of colonial capitalism'. ${ }^{1}$ The implications of this adaptive capacity should also include how Africans shaped the actions of colonial officials and their policies, to the extent that the exiguous state bureaucracy that the European colonisers

1 Ranger, 'The Local and Global in Southern African Religious History', 73. 
attempted to implement sometimes emerged out of 'ongoing negotiations and compromises with Africans and among themselves.. ${ }^{2}$ The processes of negotiation, notwithstanding colonial violence, led colonial officials to subtly consume powers generated in the marginal worlds of the colonies so that they sometimes acted by violently persecuting and punishing alleged witches, which colonial laws had denied ontological reality. ${ }^{3}$ In other contexts, the colonised were instructed to codify their 'customs', yet unlike the colonisers who regarded custom as 'ahistorical, static and to some degree unchangeable', the Malaitans (Solomon Islands), for instance, regarded their own created kastom as 'dynamic, flexible, and rapidly changing. ${ }^{4}$

If I take these ethnohistorical analyses seriously, there are no strong reasons to dwell on hybridity given that the contacts among the colonised and between the colonised and colonial state agents and missionaries was never preceded by a state of being 'pure'. Instead, my focus is on what I term post-hybridity bargaining whereby in Mozambique war survivors, community leaders and spiritual agents sometimes negotiate with state authorities the terms of their relations. Occasionally they ignore, gamble with or manipulate one another and state authorities for securing personal and culturally meaningful forms of accountability. In turn, state authorities also shift between taking diverse community agents seriously to ignoring, manipulating or exerting violence upon them as part of their attempts to shun accountability. The bricolage arrangements that shape these relations are not permanent, neither can they be predicted. Therefore, the focus should be on the politics of rebuilding social life in communities in conflict by analysing the shifting qualities of alliances made by diverse individuals and institutional and non-institutional groups, contingent modes of struggle and various meanings of violence. This type of comprehensive analysis unseats the current focus of hybridity which hastily assumes a permanent state of co-existing and overlapping political orders, predictable in their modus operandi.

My analysis is based on nearly two decades of intermittent research conducted in diverse locations in Mozambique, a country that was involved in a protracted civil war from 1976 to 1992. State authorities

2 Spear, 'Neo-traditionalism and the Limits of Invention in British Colonial Africa', 26.

3 Fields, Revival and Rebellion in Colonial Central Africa; Luongo, Witchcraft and Colonial Rule; Mesaki, 'Witchcraft and the Law'.

4 Akin, Colonialism, Maasina Rule, and the Origins of Malaitan Kastom, 6-7.

5 Stockhammer, 'Questioning Hybridity'. 
have over time denied justice for serious offences perpetrated during the war. However, my systematic focus is on the centre of the country, which since 2013 has been exposed to a new military conflict between the Frelimo Government and the armed wing of the Renamo party. For almost two decades, I conducted research in Gorongosa, a rural district with a predominantly agriculture-based economy. ${ }^{6}$ The majority of people speak 'Chi-Gorongose', and a minority also speak Portuguese. The region features political, legal and religious pluralism through the evolving presence of various local cultural groups, Christian and Muslim denominations, formal civil society organisations and state institutions.

\section{The politics of hybridity in marginal worlds}

Contemporary political analysts and policymakers have long attempted to explain the configurations of modern state institutions and political and economic orders in numerous non-Western societies around the world. Given enduring political instability, weak implementation of state institutions in national territories, and state incapacity to generate meaningful order, halt the impacts of cyclical famine and better control the spread of preventable diseases and violence, some analysts have labelled these states as fragile or failed states. ${ }^{7}$ These labels have generated further responses among academics that have either reinforced them by exploring the array of causes that sustain state fragility or contested them by advancing alternative explanations to the seeming state failure. Of interest in this analysis is the notion of hybridity, which has taken the form of hybrid political orders, ${ }^{8}$ and hybrid state perspectives and the paradigm of the transplanted state. ${ }^{9}$

Proponents of the 'hybrid political orders' concept developed it to counter top-down approaches to statebuilding. ${ }^{10}$ At the centre of these approaches are beliefs that statebuilding around the world should be modelled along the discipline of the modern Western state and that prevailing fragile and failed states in marginal worlds constitute obstacles for peace and development. Alternatively, bottom-up approaches are

6 Igreja et al., 'Agricultural Cycle and the Prevalence of Posttraumatic Stress Disorder'.

7 François and Sud, 'Promoting Stability and Development in Fragile and Failed States'.

8 Boege et al., 'Hybrid Political Orders, Not Fragile States'; Boege et al., 'Building Peace and Political Community'.

9 Chabal and Daloz, Africa Works.

10 Boege et al., 'Building Peace and Political Community'. 
highlighted in order to account for local resources, agents and dynamics involved in the production of hybrid political orders. ${ }^{11}$ It is suggested that in hybrid political orders, 'diverse and competing claims to power and logics of order coexist, overlap and intertwine, namely the logic of the "formal" state, of traditional "informal" societal order and of globalization and associated social fragmentation (which is present in ethnic, tribal, religious forms)'. ${ }^{12}$ This basic application of the notion of hybridity is useful in its attempts to tame the universal modelling and appetites of the proponents of the Weberian state. The problems with, and limits of, hybridity are highlighted by those scholars who have taken a genealogical approach to this concept as well as an ethnohistorical analysis of the encounters of Western European colonial officials and missionaries with social institutions and actors in non-Western worlds. Additionally, the limits are exposed when the concept is used to advance explanations of all peacebuilding and accountability processes around the world. In such attempts, the unpredictability, contradictions and limits of state and nonstate actors and approaches and the struggle that traverses the rusting and essentialisation of boundaries tend to be overlooked for the sake of identifying two seemingly clear-cut camps—namely, state institutions and non-state actors - which coalesce to produce a putative state of hybridity.

The late Patrick Chabal and his collaborator Jean-Pascal Daloz acknowledged that Africa experienced major sociopolitical transformations during the colonial expansion, as well as continuities in political practice from the pre- to the postcolonial period. ${ }^{13}$ Yet they argued that the European state apparatus that was transplanted to colonial Africa was different from that existing in the metropolis and it had distinct purposes. The historical analysis of colonial investment in most of the colonial worlds did not go 'beyond what was required to maintain order and a steady supply of plantation laborers and to collect taxes. ${ }^{2}{ }^{14}$ For example, the institutionalisation of property rights was absent from the colonial projects of statebuilding in much of Africa and Asia. ${ }^{15}$ Thus the notion of hybridity, which suggests an encounter between 'genuinely different societal sources that follow different logics' ${ }^{16}$ and some subsequent

11 Ibid.; Brown et al., 'Challenging Statebuilding as Peacebuilding'.

12 Boege et al., 'Building Peace and Political Community', 606.

13 Chabal and Daloz, Africa Works.

14 Akin, Colonialism, Maasina Rule, and the Origins of Malaitan Kastom, 5; Chabal and Daloz, Africa Works, 12.

15 Doyle, 'Three Pillars of the Liberal Peace', 465.

16 Boege et al., 'Building Peace and Political Community', 606. 
transformation evolving out of this encounter and post-encounter dynamics makes little sense. The ideal type of the bureaucratic state 'essentially remained a myth of the colonial mission' ${ }^{17}$ and can hardly account for some kind of meaningful hybrid outcome.

Thus, 'the paradigm of the hybrid state cannot be taken at face value since the very colonial state which was re-appropriated and re-shaped after independence hardly qualified as a modern Western institution in the first place. The colonial state was but superficially akin to its Western model. ${ }^{3} 18$ Colonial officials manipulated local values and organisation logics for maximising the exploitation of the colonies; in their turn, local elites also employed the diffuse colonial ideas of institutionalisation to protect their sources of power and advance their interests. ${ }^{19}$ Furthermore, while there has been a major tendency to neglect accounting for the role of women in these colonial and postcolonial political struggles, recent historical reanalysis based on archive materials, ${ }^{20}$ and feminist analysis, ${ }^{21}$ has contributed to shifting the current imbalances in women's contribution to world history and politics of making and breaking boundaries. ${ }^{22}$

\section{Post-hybridity bargaining}

The notion that 'a person is never complete' is a popular saying in Gorongosa as in many parts of Africa. The implications of this recognition is that many people in Gorongosa and around Africa keep inventing new techniques and medicines not to create a sense of completeness. Instead, these new but ephemeral creations are instrumental to reveal the various sources of incompleteness, and women often figure prominently in these revelations. ${ }^{23}$ Unfortunately, these cultural realities and historical developments have not figured in the analysis of the advocators of hybridity. Yet it is indisputable that the notion of hybridity has gained popular currency. It has allowed an easy and rapid circulation of

17 Chabal and Daloz, Africa Works, 12.

18 Ibid., 13.

19 Akin, Colonialism, Maasina Rule, and the Origins of Malaitan Kastom; Fields, Revival and Rebellion; Luongo, Witchcraft and Colonial Rule; Mesaki, 'Witchcraft and the Law in Tanzania'; Pels, A Politics of Presence.

20 Thornton, 'Legitimacy and Political Power'; Vilhena, Gungunhana.

21 Nye, Feminism and Modern Philosophy.

22 Argenti-Pillen, Masking Terror; Igreja and Dias-Lambranca, 'The Thursdays as They Live'.

23 Igreja, 'Negotiating Order in Postwar Mozambique'. 
knowledge of statecraft in certain sectors of higher academia as well as among policymakers of foreign affairs in industrialised nations interested, perhaps, in finding 'scientific' labels and justifications for taxpayers' money invested in those seemingly hybrid politics in marginal worlds. In this regard, I do not intend to further ruminate about the missed opportunities among scholars of hybridity. Instead, I suggest a move towards post-hybridity bargaining to acknowledge the flash popularity of the hybridity turn, but above all to properly account for the multifaceted outlook of power struggles that have unfolded in the production of embodied accountability for serious offences committed during the civil war in Mozambique.

Plunging in post-hybridity ventures is necessary because none of the various participants that I have analysed make enduring claims of representing distinct and permanent values that clash, conquer and subdue others' values. ${ }^{24}$ Instead, the reality of the various participants and structures evolves in a context of floating boundaries, which has been variously acknowledged through the proverbs 'a person is never complete', 'one leg does not dance alone' and by a state police officer, who once told me during a conversation about witchcraft: 'As a police officer I do not believe [in witchcraft], but as a human being I believe'. ${ }^{25}$ The notion that in one regime (witchcraft) a person (police) can be immune to submission and exert domination over others as well as be consumed with fear and paralysis (human being) cannot be captured by the notion of hybridity. Human beings mix and enforce boundaries as part of diverse struggles, which depend on what is at stake in each instance. From this perspective, some of the details about the struggles for accountability that I consider here may be specific to Mozambique, yet also demonstrate broader features of global struggles for justice. Internationally, there have been recurrent discussions over how to address culpability in contexts of serious offences. Over the past 30 years, national and international institutions have deployed legal mechanisms to allow witnesses to give testimonies of serious offences committed during repressive dictatorships and wars. ${ }^{26}$ However, there is often a sense of incompleteness surrounding these official practices; for many war survivors in Mozambique, and more broadly in

24 Igreja, 'Testimonies of Suffering and Recasting the Meanings of Memories of Violence in Post-war Mozambique'.

25 Igreja, 'Memories of Violence, Cultural Transformations of Cannibals, and Indigenous StateBuilding in Post-conflict Mozambique', 787.

26 Hayner, Unspeakable Truths. 
sub-Saharan Africa, justice and wellbeing and injustice and illness are related, such that addressing injustice and illness entails confronting not only the visible and quantifiable dimensions of evil but also the mechanisms and agents believed to be involved in its perpetuation. ${ }^{27}$

\section{Imaginaries of violence in colonial and postcolonial Mozambique}

The colonisation of Mozambique by the Portuguese colonial regime occurred through military, political-economic, legal and religious means. Portuguese colonial officials manipulated some of the traditional authorities known as regulo that led to the deployment of some of them as village collaborators of the colonisers. Regulo is the common name for the position of the highest chief in a village. The name regulo was created by the Portuguese colonialists but it survived the postcolonial metamorphosis in Mozambique. Yet some local leaders resisted while others were co-opted and still others joined Portuguese officials for their own self-interest, to acquire more power and defeat their local rivals. It is noteworthy that the mother of Ngungunhane, the feared emperor of the Gaza Empire (1824-1895), plotted with Mouzinho de Albuquerque, captain of the Portuguese cavalry in colonial Mozambique, to remove her son from power as he had become erratic and staged violent acts and killed many of his own people without clear imperial purposes. ${ }^{28}$

In central Mozambique, people's memories of colonisation usually focus on some of the actions of the Portuguese administrators and the cipaios, who were a group of African men used by the colonial officials as policemen to violently coerce the local populations into paying the hut tax and force them into labour camps. ${ }^{29}$ These cipaios mimicked some aspects of African magic by adopting nicknames that evoked cultural imagery and ritual violence in order to legitimise colonial power. ${ }^{30}$ The cipaios instilled fear in people, who were also ambivalent about the cipaios' violence. This was partly because of the ritualised nature of some

27 Igreja, 'Intersections of Sensorial Perception and Imagination in Divination Practices in Post-war Mozambique'.

28 Vilhena, Gungunhana.

29 Carvalho, A Guerra que Portugal Quis Esquecer; cf. Akin, Colonialism, Maasina Rule, and the Origins of Malaitan Kastom.

30 Igreja and Skaar, "A Conflict Does Not Rot”. 
of the violence and because of the cipaios' determination and sense of responsibility and loyalty to their colonial masters during the fulfilment of their duties. The cipaios persecuted individuals who failed to pay the hut tax and fugitives accused of committing serious offences and brought them to the colonial administrator who rendered official justice himself, instead of 'a magistrate sitting in a court of law' as was the case in Europe. ${ }^{31}$ In spite of working for the colonisers, the cipaios'sense of commitment and courage lured the local populations which culminated in the integration of the figure of the cipaio into the category of spirits named mucipai (plural of cipaio in Chi-Gorongose language) in the apparatus of local healers. Mucipai resisted the erosion of time and are the spirits that help healers to search for clients in a rather similar logic of the cipaio who used to uncompromisingly hunt his prey.

In 1962 the Mozambique Liberation Front (Frente de Libertação de Moçambique; Frelimo) was founded to wage a war for independence against the Portuguese. The country attained independence in June 1975 at the height of the Cold War. As in other socialist-inspired revolutions, the Mozambican state officials appeared versed in so-called 'scientific socialism'; they banned various religious and cultural practices and arrested and executed individuals believed to be involved in 'obscurantist practices' and regarded as 'enemies of the people'. ${ }^{32}$ The legacies of the colonial rivalries among various nationalist groups in tandem with the postcolonial revolutionary excesses and the politics of the Cold War gave birth to a civil war (1976-1992) that pitted the Frelimo Government against the Mozambican National Resistance (Resistência Nacional Moçambicana; Renamo).

It has been estimated that one million people died and four million became internally displaced persons and refugees. Both armies fought for the control of populations in order to sustain the war. People under government control lived in communal villages, whereas people in Renamo areas lived in madembes (old residences). Renamo took advantage of the resentment harboured by the local leaders and their people and allowed local leaders, healers and Christian churches to operate in their zones of control. Throughout the country were numerous reports of abductions of men and women, and children were used as soldiers; there were frequent

31 Chabal and Daloz, Africa Works, 12.

32 Igreja, 'Frelimo's Political Ruling through Violence and Memory in Postcolonial Mozambique'; West, Kupilikula. 
reports of forced marriage of young girls, and sexual violence against women. ${ }^{33}$ Some parents compelled their young children (boys and girls) to hasten marriage as a potential protection against humiliation and loss resulting from rape, while other young girls did ku toera mabota ('go after the boots', meaning soldiers, to flirt with them) to survive. ${ }^{34}$

Cultural and religious rituals were as much implicated in the making of war as of peace. ${ }^{35}$ During the early years of the civil war, Renamo soldiers used piça wega (burn yourself). After assaulting a communal village, the soldiers compelled the people to remove valuable objects (related to magic) from inside their huts and then forced them to set their huts on fire. This was to prevent the soldiers and the villagers from being persecuted and afflicted by magical spells. Burning the huts was a violent act and dispossessed the people, but the burning took into account people's magical and religious traditions. The recognition of magic and the necessity to act accordingly also revealed the soldiers' sense of fear in relation to the power of local traditions. Such a posture conferred a measure of legitimacy to the broader purpose of the war on the side of Renamo.

The civil war was aggravated by periods of severe drought and ensuing famine, particularly in 1987-1988 and 1990-1992, which claimed many lives. At the war's end, war survivors attempted to forgive and forget and move on without accountability. Yet forgetfulness was not always possible as war survivors were compelled through cultural processes to address their deeply unsettled divisions as a basis for a life in common. ${ }^{36}$

\section{Peace agreement: Spaces of autonomy and amnesty law}

Following the collapse of the Soviet Union and the end of the Cold War, at the end of the 1980s the Frelimo Government engaged in regime change. It adopted a democratic constitution in 1990, which expanded citizens' rights by recognising cultural and religious pluralism, freedom of expression, economic liberalisation and a multi-party democratic system. Through two years (1990-1992) of brokered negotiations,

33 Nordstrom, A Different Kind of War Story; Schafer, Soldiers at Peace.

34 Igreja, 'Media and Legacies of War'.

35 Lubkemann, Culture in Chaos.

36 Igreja, 'Cultural Disruption and the Care of Infants in Post-war Mozambique'. 
Renamo was swayed to recognise the legitimacy of state institutions under Frelimo rule and the Acordo Geral de Paz (General Peace Agreement), consisting of seven protocols, was signed in Rome on 4 October 1992. The Frelimo Government agreed to attribute a space of autonomy for the traditional structures of governance, which created a dual ruling regime and was sealed in Protocol V 'On Guarantees' of the peace agreement.

Protocol V of the General Peace Agreement created pluralist and decentralised spaces whereby war survivors could engage in serious, albeit unpredictable, struggles for a whole range of rights including, although not stipulated, accountability for wartime offences. Yet 10 days following the signature of the peace agreement, the Frelimo Government passed an unconditional amnesty law (Law 15/92) exempting everyone involved in the civil war from criminal prosecution. ${ }^{37}$ The amnesty law was followed by legal reforms that were publicly intended to create democratic institutions and practices based on scientific methods. ${ }^{38}$ Of particular relevance for this analysis was the development of legal provisions that granted further autonomy to community leaders, ${ }^{39}$ namely the Decree Law 15/2000 of the Autoridade Comunitária (Community Authority), which legally recognised various community leaders. ${ }^{40}$ Within this context various civil society organisations were legally formalised such as one of traditional healers, known as Associação dos Médicos Tradicionais de Moçambique. Yet over time when the Frelimo Government realised that it was no longer harvesting the dividends of decentralised politics through control of politics at community level, the party cadres legally reverted to centralised modes of ruling. ${ }^{41}$

\section{Pluralist social orders and embodied accountability}

The state amnesty law did not manage to silence war survivors nor put a lid on struggles for accountability in postconflict Mozambique because of the pluralist nature of perceptions and practices of social orders, disorders, wellbeing and illness, justice and injustice. Ironically,

37 Hayner, Unspeakable Truths; Igreja, 'Amnesty Law'.

38 Igreja, 'Memories of Violence', 780.

39 Igreja and Skaar, "A Conflict Does Not Rot".

40 Kyed, 'The Politics of Legal Pluralism'; West, Kupilikula.

41 Igreja, 'Politics of Memory, Decentralisation and Recentralisation in Mozambique'. 
the Frelimo Government and main opposition party, Renamo, were also not successful in their vows to forget the past and focus solely on development. The newly created multi-party parliament was established in 1995 and mirrored a melting pot of diverse and hastily digested institutional influences and practices of the colonial minimalist state structures, Frelimo's postcolonial revolutionary enthusiasm and excesses, and the civil war techniques of psychological warfare. As the new multiparty parliament initiated activities, both parties broke the silence and used memories as weapons that denied one another political legitimacy. ${ }^{42}$ Yet when parliamentary discussions focus on salaries and other member privileges, both Frelimo and Renamo parties speak in unison, and regard one another as brothers. This behaviour provides further evidence of how the divisions and symbiosis are not permanent.

At the community level and in war-torn regions such as Gorongosa, struggles for justice were manifested through protracted family conflicts and severe bodily symptoms triggered by the spirits of the dead, which returned to the realm of the living to disturb the alleged perpetrators and their kin. ${ }^{43}$ In this regard, accountability is an embodied phenomenon, in the sense that it is inseparable from the lived experiences of war survivors, their relatives and postwar generations. Embodied accountability means that alleged perpetrators and their victims become tied through the suffering that shatters their bodies and everyday lives, thereby compelling both perpetrator and victim and their kin to act in the pursuit of truth and justice. ${ }^{44}$ The victim seeks justice in local cultural terms, whereas the alleged perpetrator seeks resolution because he or she lives with a reputation of embodying tserusso. Tserusso means that the individual is often suspected of being an evil person. Such a reputation amounts to a form of social incarceration. The imprisoned person is known to be enveloped in a world of tchidimadima (mystery), which severely limits the person's pursuit of a life of communality and dignity. Since persons are not understood as autonomous individuals, 'but as nodes in systems of relationships' ${ }^{45}$ serious violations also affect the wellbeing of the kin group of the alleged perpetrator, so that certain forms of guilt are also collective. Thus, in this sociocultural setting, health and illness is inextricably linked to the sense of justice and injustice, and certain experiences of illness and

42 Igreja, 'Memories as Weapons'.

43 Cf. Mueggler, The Age of Wild Ghosts.

44 Igreja, 'Legacies of War, Healing, Justice and Social Transformation in Mozambique'.

45 Ferguson, 'Declarations of Dependence', 226. 
injustice are expressed in ways that escape the control of the suffering person and kin group. From this perspective, it is useful to think in terms of post-hybridity bargaining because it is not possible to predict when the embodied accountability will be placed en demarche for everyone to see and act accordingly. While it is known that embodied accountability can be expressed through the mediation of spirits of the dead in male and female bodies (although more prominently female bodies), still it is impossible to know beforehand which alliances (or no alliances) will be mobilised among community leaders, Christian and Islamic leaders, state police and judicial courts in order to attempt a resolution for war-related unresolved conflicts. ${ }^{46}$

In this region, the spirits are regarded as persons with their own volition, ${ }^{47}$ and their rules are regarded as possessing autonomy from and power over the living. This conception evokes forms of personhood, whereby agency and subjectivity are also attributed to spiritual and natural agents, and these are continuously negotiated with the living. ${ }^{48}$ The rules of the spirits and the changing customs of the living determine the seriousness of a breach and the type of resolution that should be followed. The most serious offences occur when people die from unjust death triggered by physical violence, extreme negligence or refusal to provide care. Such cases are considered as serious offences and unforgivable unless there is resolution. The rule is micero ai vundi-a conflict does not rot or disappear until it has been redressed. ${ }^{49}$

\section{Gamba spirits, embodied accountability and post-hybridity bargaining}

In the past two decades, I have had the opportunity to witness diverse struggles for accountability. The majority of accountability cases I came across were related to serious offences perpetrated during the civil war. Following the civil war, gamba (plural magamba) spirits came to take over processes of war-related accountability. Gamba refers to spirits of male

46 Igreja, 'Traditional Courts and the Struggle against State Impunity for Civil Wartime Offences in Mozambique'.

47 Boddy, Wombs and Alien Spirits; Kwon, Ghosts of War in Vietnam; Lambek, Knowledge and Practice in Mayotte; Masquelier, Prayer Has Spoiled Everything.

48 Igreja, 'The Politics of Peace, Justice and Healing in Post-war Mozambique'.

49 Igreja and Skaar, "A Conflict Does Not Rot". 
soldiers who died during the civil war. Following the war, gamba spirits became vengeful and demanded justice for wartime violations. These spirits also evolve to use the bodies of some of their hosts, particularly women, to work as gamba healers. ${ }^{50}$ In this regard, women have become central to processes of coming to terms with the diverse legacies of a modern warfare as it was waged in the country's war theatres. Gamba spirits bear witness to some of the grisly events that unfolded in the context of tripartite relations involving soldiers, families and communities. These spirits prefer to speak through the bodies of the alleged wrongdoers or their relatives, and this is manifested through altered state of consciousness, which paves the way for voicing indictments against alleged perpetrators. Following gamba spirit possession episodes, the spirit's host gets post-facto amnesia (unable to recall what happened). Gamba spirits refuse the attempts of the local people and central government authorities to discreetly appease them; they want accountability through public indictments and deliberations to denounce the culprits of serious offences perpetrated during the civil war. If such performances are not offered, the host is doomed to suffer. The continuity of torment is part of the local ethic of reciprocity, which holds that conflicts stemming from serious injuries leading to death continue unless they are appropriately redressed. Specifically, during possession, gamba spirits publicly re-enact war-related events, make indictments and, while doing so, are violent towards the host's patri-kin. To the audience these performances evoke war memories that had been hidden and for the host/ patient these performances evince severe suffering.

While it is known that present circumstances, often involving ongoing social suffering and interpersonal conflicts, can trigger serious disputes about violent events from the civil war, these circumstances do not determine whether disputes will escalate into open conflict centred on accusations of wartime offences. The manifestation of open conflicts, often mediated by gamba spirits, can mean that the parties involved failed to reach a compromise which could have entailed staging public performances of acknowledgement of wrongdoing. ${ }^{51}$ Depending on the severity of the problem and in case one of the parties refuses to collaborate, the plaintiffs can increase their bargaining power by consulting a healer, community court, religious authorities or the offices of the state police and judicial court. ${ }^{52}$

50 Igreja, 'Mozambique'.

51 Igreja, "'Why Are There So Many Drums Playing until Dawn?"'.

52 Igreja and Racin, 'The Politics of Spirits, Justice, and Social Transformation in Mozambique'. 
It is noteworthy that some litigants take their war-related disputes, albeit often masked in idioms involving spirits or witchcraft, to the police or judicial court when, in principle, these institutions are driven by secular projects and it is known they have no legal mandate to deal with such cases, given the amnesty law. Comparative analysis can shed some light on these conundrums. Peter Pels has suggested that since the earlier days of contact between European administrators and missionaries and the Waluguru people (Tanzania), the former regarded magical acts as religious, whereas the Waluguru regarded spirits and witchcraft as 'something to be countered by secular means and they failed to see why missionaries had to interfere, and government was loath to cooperate, in a secular measure for the common good'..$^{53}$

When war survivors engage with the police and the justice sector in Mozambique, they enshroud their war-related disputes in the language of spirits in order to circumvent the amnesty law. State officials (district level) know that the amnesty law impedes both the police and the people from evoking serious offences of that era. Yet when the conflict appears enshrouded in the 'invisible realm', ${ }^{54}$ the police can refer the case to healers. Nevertheless, the ultimate course of action is contingent upon the police officer in charge of the police station when the problem is brought to their loose jurisdiction. Depending on the discretion of the officer in charge, there is a likelihood that a kind of handwritten subpoena is issued to compel one of the defendants to show up, either in the consultation yard of the healer or in the community court. ${ }^{55}$ Occasionally, the police officer can wink at the litigants and indicate that he/she is thirsty or lacking credit on his/her mobile phone, which means that, should the plaintiff pay the officer a discreetly negotiated fee on the spot, the officer can accelerate family reunion to try out a resolution by bringing with him/her the weight of the bureaucratic state structure (through wearing the police uniform and carrying the AK- 47 weapon) to bear on the defendant who has refused to collaborate with family members. Still, on other occasions, the state official can embody state fragilities and find himself or herself trapped in beliefs of spirits and witchcraft both as a police officer and as a human being, thereby becoming personally interested in the case.

53 Pels, A Politics of Presence, 245.

54 Stroeken, Moral Power; West, Kupilikula; Wiegink, 'Why Did the Soldiers Not Go Home?'.

55 Igreja, 'The Politics of Peace'. 
Thus, the officer can show up later, out of uniform, at the healing session to gain further knowledge that can be instrumental to allegedly defend himself and the state. ${ }^{56}$

Additionally, depending on the gravity of what is at stake, the police commander can request the services of healers to cleanse the police station and vaccinate willing police officers with magical potions, given the putative pollution left by alleged witches who had been arrested and held in the police prison cells. ${ }^{57}$ Occasionally, the activities of state officials can expand to involve the district administrator, as was reported in the Ibo district of Cabo Delgado province in north Mozambique with a predominantly Muslim population. The local administrator granted support to Associação dos Médicos Tradicionais de Moçambique to engage in compulsory homestead surveillance actions to detect alleged witches and punish them appropriately. ${ }^{58}$ One of those alleged witches was a maulana (a Muslim man revered for his religious learning or piety), who claimed that the healers invaded his house, shaved his hair and grabbed his Koran under the justification that they were searching for witchcraft.

Despite these alliances between state officials and healers, when state officials need a public sacrifice in order to expand broad base support and convey a sense of strength and control of intimate district life, they can arrest healers under the justification that they violate state laws by using excessive force and violence against alleged witches. In turn, healers can initiate a public defamation against the police under the justification that the police do not know what is required to subdue witches and maintain social order in their communities. ${ }^{59}$ Lastly, sometimes war survivors approach the police in ways that both acknowledge and rebuff their existence by reverting to a kind of radical metaphysics that seemingly makes it difficult for secular-driven mindsets to break the boundaries of inner logics. For example, I once participated in the resolution of a serious conflict involving a maternal grandfather and grandson, which led to a criminal offence perpetrated by the young man that almost killed his grandfather. After first aid was performed at the district hospital, the nurses referred the case to the police given that in principle only the

56 Igreja, 'Justice and Reconciliation in the Aftermath of the Civil War in Gorongosa'.

57 Igreja, 'Memories of Violence'.

58 Canalmoz newspaper, Maputo, 15 April 2013.

59 Igreja, 'Memories of Violence'. 
police have jurisdiction over serious physical injuries. When the litigants presented the case in the police station, they informed the police officer that the old man had been beaten by a spirit. The officer said 'the spirit might have been very strong to cause such a serious injury'. He transferred the case without enquiring how a spirit could have actually inflicted the physical wounds the victim had in one of his ribs. Given the gravity of the case, which the police have sole prerogative to deal with, it is seemingly incomprehensible why the police officer gave full autonomy to the people involved by not raising questions to clarify how a spirit could have caused those bleeding wounds. The victim, who could hardly speak to present his version of the events, saw his grandson walking free from the police station, and they headed to the healer's association for follow-ups.

This example elucidates that, in the relations between state agents and the people and among the people themselves, there are no permanent boundaries nor stable bricolages. These relations can be better understood when viewed through the lens of bargaining practices for a convenient order. This means that in these power contests, sometimes each side interpenetrates whereas at other times they raise their boundaries to cogently claim spaces of differentiation and autonomy, so that neither the interpenetration nor the sense of differentiation become a permanent state of affairs. Sometimes the people bond to increase their bargaining power. This was the case with the gamba spirits, which allowed many war survivors to attain personal and culturally inspired forms of justice. ${ }^{60}$ Other times, the same people manipulate one another while establishing alliances with state actors (administrator, police and judiciary) to pursue personal interests. In turn, state actors also selectively make and break alliances to pursue personal and alleged state plans.

\section{Conclusion}

In closing, the notion of post-hybridity bargaining draws attention to the analysis of a more complex set of relations involving spirits, people and various state institutions and actors. These relations are not unidimensional given that the various participants acknowledge their multiple identities as in the case of the police officer who is also

60 Igreja et al., 'Gamba Spirits, Gender Relations, and Healing in Post-Civil War Gorongosa, Mozambique'. 
a human being; a leg that cannot dance alone therefore always searches for a complementary one; a person who is never complete thus always reverts to other persons, animals and nature more broadly, not to capture some sense of completeness but to reveal the sources of this incompleteness. In this regard, these notions and the practices they entail cannot be bounded by the notion of hybridity and the sense of stability that hybridity evokes. Post-hybridity focuses on the ongoing fashion and refashion of social life according to what really matters for the people in a given predicament.

From a policy perspective there is little doubt that the implications of the processes I have described and analysed here are marred with complexities. While acknowledging the intricate role played by diverse local structures, agents and resources is an important step, it is nevertheless not simply a matter of hastily financing them with the expectation that these agents and processes can become formalised and predictable. The conundrum is that unpredictability and malleability are key sources of innovation and social change. In this way, policymaking initiatives should include ways of empowering existing resources and agents without attempting to block their creative drive. From the perspective of posthybridity bargaining, policy initiatives need to be experimental in most communities in conflict. For example, one experimental policy area could focus on specifically acknowledging the central role played by women in accountability processes for some of the serious offences committed during the civil war in Mozambique; ${ }^{61}$ another policy area could promote the organisation of women in ways that boost and spread accountability practices to other areas of social and political life such as marital practices, domestic violence, corruption in community and state institutions, and educational sector and economic entrepreneurship.

61 Igreja, 'Traditional Courts'. 
This text is taken from Hybridity on the Ground in Peacebuilding and Development: Critical Conversations, edited by Joanne Wallis, Lia Kent, Miranda Forsyth, Sinclair Dinnen and Srinjoy Bose, published 2018 by ANU Press, The Australian National University, Canberra, Australia.

doi.org/10.22459/HGPD.03.2018.10 